\title{
The Orwellian "Amerika" of Donald J. Trump?
}

\author{
John Rodden ${ }^{1}$
}

Published online: 5 June 2020

(C) Springer Science+Business Media, LLC, part of Springer Nature 2020

\section{Abstract}

Is President Donald J. Trump really George Orwell's Big Brother in the flesh? Ever since Trump's inauguration in January 2017, the mainstream American media have depicted him as such, with his defenders in the conservative press and broadcast outlets accusing his opponents of doublethink and thoughtcrime. This article examines the extraordinary way in which the Trump administration has become a magnet for the language of Newspeak, a contested site where the catchwords of 1984 are bandied ceaselessly by his allies as well as his adversaries.

Keywords Donald Trump. George Orwell $\cdot 1984$ · Orwellian · Animal Farm · Newspeak · Doublethink · Thoughtcrime · Davos · McKay Coppins · Victor David Hanson · Rudy Giuliani · Kellyanne Conway

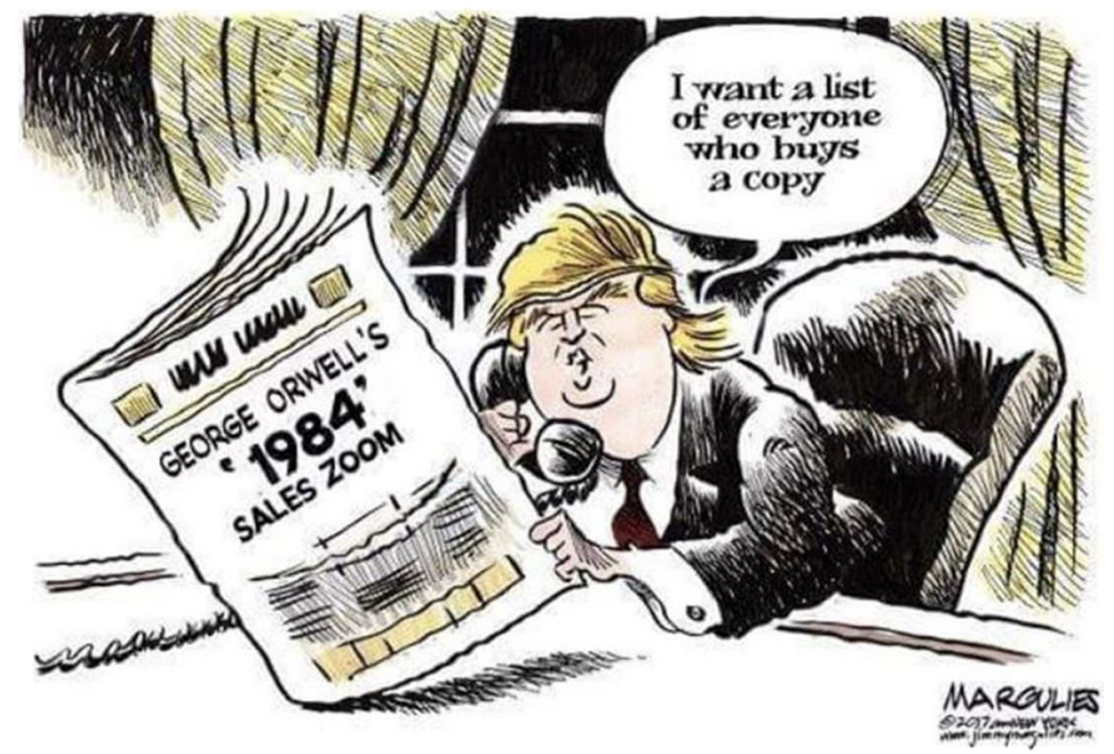

\section{Here we Go Again, George!}

Even before the worldwide obsession with the Covid-19 pandemic took hold in late February 2020, whereupon

John Rodden

jgrodden1@gmail.com

1 Program in British Studies, Harry Ransom Research Center, University of Texas, Austin, TX 78712, USA much of the American media began to attribute its spread to the contagion sheltering in the White House for more than three years in the form of President Donald J. Trump, comparisons between the president and George Orwell's Big Brother had already gone corona-viral. Rather than focus here on this newest wave of analogies and satiric references, however, let us step back and ponder the history of how Orwell's bogeyman dictator has in many circles virtually become a synonym for the American president. 
Just a few months ago in March-yet seemingly light years in terms of the cataclysmic changes that have been introduced into daily life-in a blistering cover story in The Atlantic on the approaching American presidential election ("The 2020 Disinformation War"), staff writer McKay Coppins charged that President Donald J. Trump has built a billion-dollar "disinformation campaign," whereby "a dystopian picture of the general election comes into view." Coppins, a regular guest on CNN and MSNBC and formerly a BuzzFeed staff member, portrayed the president as a thuggish, Big Brotherish leader. (For his part, Trump has denounced Coppins as "a dishonest slob.") Casting the Trump election campaign in Orwellian terms, Coppins predicted that the president's gale-force swirls of propaganda will deal a death blow (and perhaps sound the death knell?) of "fact-based journalism." The article stirred much discussion, occasioning numerous commentaries in reply, such as the headline on the website of the left-wing First American Coalition: "Brace Yourself for the Coming World of Orwell's 1984."

Braced we are - once again. Or perhaps better: as always.

Yet another American presidential election is around the corner. And just as has occurred in every previous election season - stretching back at least to the eras of Richard Nixon and Ronald Reagan in the 1970s and '80s - the agitprop language and "dystopian" vision of George Orwell's Nineteen Eighty-Four (or rather 1984, per the Newspeak-like American title) represent a significant shaping force in the media's analysis and the candidates' rhetoric.

\section{Right Hooks and Left Uppercuts}

Lest we forget: the "Orwellian" campaign is not just limited to making use of 1984. In late January, just days before the online version of Coppins's Atlantic article appeared, Gerard Baker in the Wall Street Journal described the annual World Economic Forum meeting of international business and government leaders as a barnyard festival worthy of the pigs and their comrades in Animal Farm. Headlined "For Liberal Elites at Davos, Some Are More Equal Than Others," Baker's article counterpunched with sharp right hooks. Noting that the address of their special guest and keynote speaker, Donald J. Trump, "was received in almost total silence," Baker began: "The leaders gathered in the Swiss Alps call to mind the [pig] rulers of George Orwell's Animal Farm...."

Of course, the Wall Street Journal was firing from the Right, not the Left, at a favorite political target- "liberal elites." This conservative critique has certainly not been the lone prominent attempt recently to shift Orwell's coffin á la droite. Best known for his appearances as a guest commentator on Fox News, Victor David Hanson, a military historian and resident scholar at Stanford University's Hoover Institution, has repeatedly invoked Orwell and 1984 in his statements about the ideological and cultural politics at issue in the American presidential campaign. In one article last winter, "The Looming 1984 Election," Hanson prophesies that, "like it or not, 2020 is going to be a plebiscite on an American version of Orwell's 1984." Arguing that the president has faced crazed attempts to undermine his authority from Democratic Party politicians and their allies (culminating, of course, in their failed attempt at impeachment), Hanson says that "Trump also fights back" on all fronts, "from the existential to the trivial." Trump's fusillades include, says Hanson, his indefatigable tweeting against left-wing sports heroes such as [American football quarterback] Colin Kaepernick, his "tit for tatting" Hollywood icons, his ready condemnation of "radical abortion" advocates, along with supporters of irresponsible positions associated with sundry topics like "open borders, power outages, the homeless, and subway jumping."

Numerous other left-oriented publications have rushed to man the barricades for "the looming 1984 election." In Wired magazine last December, tit-for-tatting over Victor David Hanson's head and taking aim at the Fox News network itself, Garrett Graff agreed with other liberal and leftist commentators that the death of fact-based journalism is upon us. In Graff's opinion, however, this has less to do with Trump himself than with "journalists." (The skeptical quotation marks are Graff's own.) Graff concluded: "Facts that are inconvenient to President Trump simply disappear down Fox News's memory hole as thoroughly as George Orwell would have imagined in 1984."

Perhaps a columnist from Orwell's birthplace, India, writing in The Hindu, summed it up best. Concluding his article devoted to "Why Orwell Matters Today and Why He Will Continue to Matter," Suresh Menon revealed that his meditation-which reflects a worldwide habit among political journalists and intellectuals - had become, "When I find myself in times of trouble, George Orwell comes to me." Indeed, whether or not "St. George" Orwell can relieve our troubles, he - and his dark twin, the "Orwellian" architect of Newspeak-is unquestionably invoked in myriad contexts, testifying not only to his dystopia as a universal metaphor, but also to the "saintly" George Orwell and diabolical "Orwellian" as well.

Yes, George Orwell and 1984 are ubiquitous in American public discourse, even more widespread this year than usual. Their omnipresence in 2020 America "trumps" other times and places, since the quadrennial presidential campaign season furnishes countless new opportunities to equate virtually every action and statement of the president (and the rival candidates) with Big Brother, Newspeak, thoughtcrime, and the evil empire of Oceania. Beyond this recurring event, however, the phenomenon of Donald J. Trump represents the cynosure of all eyes, with our gaze transfixed on every Trump tweet, invariably twitting and tweaking the noses of l'homme (ou la femme) du jour. With Trump on the stump, some elections are 
more equal - er, more "Orwellian"-than others (irrespective of your opinion, pro or con, of the president).

Still, while "Orwell and 1984" pervade, or even saturate our political discourse, their prevalence is by no means simply owing to a presidential election year or the current Oval Office occupant. It also has to do with factors intrinsic to the book itself and attributable to the genius of Orwell's language and vision. That is, Orwell and the catchwords of 1984 are also more bannered in headlines and blared in tweets than ever before because the coinages and neologisms of 1984 serve as universal metaphors for and monikers of our present international condition, pertaining to issues ranging from state tyranny and personality cults to bureaucratese and corrupt official (and commercial) language, privacy invasion, and every conceivable sort of encroachment against civil liberties and infringement against personal freedoms.

\section{The Ministry of Alternative Facts?}

Despite the Dantean universality of George Orwell's political Inferno, Nineteen Eighty-Four, it warrants re-emphasis that the ubiquity of his name and novel in the Trump era is without precedent. Literally from Day One of the Trump administration-well, make that Day Two - they have not only formed the stuff of headlines but also commanded headlines themselves. This astounding history is worth recalling - not only for itself but for what it reveals about the uses and abuses to which George Orwell's name and work are put.

On January 21, 2017, Day Two of the new American president (yet actually his first full day) in office - and perhaps ominously, the sixty-seventh anniversary of George Orwell's death-1984 began yet another incredible climb toward the peaks of the bestseller lists. A series of public statements by senior officials in the new administration had catapulted it to No. 2 within hours of Trump's swearing in. White House press secretary Sean Spicer heatedly insisted that the inauguration had been the best attended ever_- "period"-regardless of what the photo and statistical evidence might indicate. Two days later, on the Sunday morning television show Meet the Press, Kellyanne Conway, a close advisor to the president, defended Spicer by "explaining" that his false claims were merely "alternative facts." Conway's notorious phrase immediately went viral and was translated into numerous languages. Alarms rang out across the globe that Winston Smith could not have come up with a better line in his cubicle at the Ministry of Truth, where all fabrications are merely what could be termed "alternative facts."

And by the morning of January 25, 1984 stood at No. 1for an amazing fourth time since its publication 70 years earlier on June 8, 1949. A widely syndicated cartoon two days later captured that moment, charging that Trump was keeping tabs on the New York Times (or some other purveyor of allegedly left-slanted "fake news"). The cartoon mocked Trump as an "Orwellian" leader who is keeping an allseeing eye on any "enemy of the people."

In an interview with CNN, I dubbed Conway, whose inadvertent masterstroke of euphemistic Newspeak suddenly made her the darling of the publishing industry, the "Oprah of the Oval Office," a wonder woman who could immediately turn serious books-above all, dystopian classics-into bestsellers. (Within weeks, the rising tide of 1984's sales also lifted Margaret Atwood's The Handmaid's Tale to No. 1, with classics such as Aldous Huxley's Brave New World and Orwell's own Animal Farm in hot pursuit.)

Throughout the USA, "liberal elites" and most media outlets (Fox News excepted) issued red alerts urging operational readiness: the Orwellian "Amerika" of Donald J. Trump was underway.

\section{Ignorance Is Strength—When “Truth Isn't Truth"?}

And it has been that way ever since. To wit:

Fast-forward 18 months. In August 2018, another choice example of Newspeak - this time by the president's lead lawyer, Rudy Giuliani-drew another round of countless references to Orwell and may even have "trumped" Conway's howler. "Truth isn't truth," said Giuliani, replying to an interviewer's comment that the president should just "tell the truth" if he met with the team of Robert Muller, the special counsel at work on investigating the president and other Trump administration officials about their connections to Russia and its alleged interference in the 2016 presidential campaign. Giuliani made the statement during a Sunday morning Meet the Press television appearance (August 18) in the course of explaining that he was advising his client not to testify before the special counsel since the president might make a statement that could lead to a perjury charge.

The outcry from both the media and political liberals about Giuliani's "Orwellian" line was loud and immediate. Analogies were drawn between the disappearance of "objective truth" in Orwell's Oceania and life in "Trumpland." Headlines such as New York Magazine's "Giuliani Goes Full Orwell" were also common-here again conflating and confusing Orwell with his "Orwellian" doppelgänger, "Orwell."

As much as the political pundits enjoyed the hilarity of Giuliani's blooper, book publishers took less delight in it, for unlike the case of Conway's blunder, Giuliani's remark had no discernible effect on sales of any books, including 1984.

Obviously, the sales of 1984 during the last four years have risen in response to Trump's audacious attempts to manipulate facts throughout his long presidential campaign and since his 
November 2016 election victory. It is interesting that the connection between "alternative facts" and Orwell's dystopia was first made by a reporter who dubbed it "a George Orwell phrase" - as if Orwell himself might have been a Winston Smith who crafted his lies in clever-sounding language or even a version of Donald Trump.

\section{The "Saintly" Orwell and the Spectral "Orwell"}

This confusion about and conflation of the author George Orwell with such "Orwellian" locutions is a common occurrence. Is "Orwellian" language the limpid, direct style of the author? Or is it the diabolical doublespeak of Big Brother? Certainly in the public mind - and in common usage - that proper adjective mainly signifies the latter. And this sinister meaning of the man's name in adjectival form reflects the rise of what can be called the "Orwell legend," that is, the transformation of an individual into an icon. All this points to the difference between Orwell and "Orwell," with the latter representing the towering totem invoked by ideologically motivated (or ill-informed and careless) observers to bolster whatever arguments they seek to advance.

The association of Donald Trump with Orwell reflects how a man of letters, the writer George Orwell, is transformed into a titanic totem, the icon "Orwell." That distinction was overlooked during the media's feeding frenzy about "alternative facts," which eclipsed and elided the writer Orwell into the bête noir "Orwell."

Alas, the tendency is widespread, certainly not limited to Trump's circle. And sometimes the "confusions" are not at all accidental, but rather direct, frontal attacks on Trump and Orwell together.

Consider, for example, one of the most thoroughgoing attempts during the runup to the 2020 election to link and liken President Trump and George Orwell. In a 2,000-word critique ("The Real Parallels Between Donald Trump and George Orwell"), a left-wing Trump critic writing online for CounterPunch demonstrates that "Ignorance Is Strength" is by no means under copyright by the political Right. The author, Nick Pemberton, casts Orwell himself (!) as a Deep State operative, indeed a forerunner of President Trump.

Leading off with an epigraph from Noam Chomsky charging Orwell (who had served in Burma as an Empire police official in his early 20s) as "for almost twenty years [thereafter] the policeman of the Left," Pemberton proceeds:

One could argue that George Orwell was one of those leftists who criticized the Deep State for the right reasons. However, when we look closely... we see that Orwell had many prejudices he hid behind closed doors.... George Orwell and Donald Trump literally say the same thing: it is all fake news.
The author concludes:

George Orwell is like Donald Trump in some ways. He has no loyalty to anyone but himself. He despises government, especially when it is in the name of socialism. $\mathrm{He}$ is racist, homophobic, and anti-Semitic. He is driven by his egotistical sexual urges more than any ideology. Bad writers have only one story to tell, and it's their own. 1984 was such a story. George Orwell snitched out his comrades to a member of the secret police he was in love with.... Donald Trump, who has no friends, and George Orwell, the snitch who proved that he had no friends he cared for, have a lot in common.

The indictments here are familiar; Orwell's Marxist detractors have been levelling variants of them for more than seven decades, refurbishing and updating them as opportunities arise and circumstances permit. A typical gambit is to confuse and conflate Orwell with his "Orwellian" creation, Big Brother.

The presumed kinship between the man and writer (Orwell) and the bogeyman behemoth ("Orwell"), which serves to blur or completely efface any distinction between them, bears comparison with the perplexing mix-up between Dr. Victor Frankenstein and his mutant monstrosity. Among those who have never read Mary Shelley's Frankenstein, "Frankenstein" is the monster-not unlike the case with Orwell and Big Brother (or "Orwellian" and "Ingsoc-ian," to coin a jarring Newspeak-ism!) It warrants emphasis, however, that Dr. Frankenstein's Promethean creation - which he variously refers to as "creature," "being," "thing," "spectre," "wretch," "fiend," "ogre," and "demon"-remains nameless in the novel. In a passing remark, the monster does address himself to Dr. Frankenstein as "the Adam of your labors," imputing godlike power to his creator.

Mudslinging about fake news, scandals galore, political gridlock, and internecine inside-the-Beltway warfare notwithstanding, Trump has proven a master at dominating the airwaves. It is as if he based his entire campaign strategy and governing outlook on the famous party slogan in 1984: "Who controls the present, controls the past. Who controls the past, controls the future." The president has understood that the takeaway is this: whoever controls the present controls both the past and the future. Such a tremendous power to command headlines and dictate the public conversation of the momentexemplified by his direct connection to the wider public via his hyperactive Twitter account-is a terrifying demonstration of what Orwell termed the "mutability of the past."

\section{"IF Orwell Were Alive Today..."}

More than likely, if he were alive today, George Orwell would be a target, not an ally of the president. In that event, while the 
American print and broadcast media have preoccupied themselves since 2016 with the question, "What would Orwell say about Donald J. Trump?", it is worth asking, "What might Donald Trump say about a crotchety Orwell upbraiding Trump for one of his diatribes about 'fake news' or 'crooked Hillary' or 'shithole countries'?" One can imagine a Trump tweet against him: "A total loser! Not a clue! Park yourself in Room 101 and open the rat cage."

Yet is Donald Trump the only president to be tarred with the "Orwellian" brush? Not at all. True, the release of and surrounding controversy over Robert Mueller's investigative report of the president in 2019, along with Trump's dubious phone call in July 2019 to the Ukrainian president, escalated into the impeachment and trial (without conviction) of Trump.

It is worth noting, however, that the calls to "impeach Big Brother" did not begin with Trump and the aftermath of the 2018 midterm elections in the U.S., which witnessed control of the House of Representatives shift to the Democrats and the start of congressional investigations to impeach him. My research has turned up numerous cartoons and news articles satirizing "Big Brother" Ronald Reagan, who also confronted scattered calls for impeachment from his political opponents. Attempts to impeach Reagan never gained strong congressional support. In 1999, however, the case turned out quite differently for Democratic president Bill Clinton, who was impeached by a Republican-led House in December 1998, though not convicted by the U.S. Senate two months later. Especially during the occupation of Iraq, George W. Bush was satirized as "Orwell Man" and his successor was labeled "Big Brother Obama," with protesters chanting mockingly, "Yes We Scan" (a derisive pun on his popular 2008 campaign slogan, "Yes We Can").
Admittedly, both the stagecraft and substance of the Trump administration's foreign policy are quite different from those of Barack Obama and even George W. Bush. If anything, however, civil liberties seem under siege to an even greater extent today. And whatever one writes about the topic is soon hopelessly dated. Exposés uncovering the skullduggery of Cambridge Analytica, the misuses of Facebook data, and the Soviet and Chinese governments' officially sponsored hacking programs reveal vertiginous quantum leaps in techno-tyranny on an almost weekly basis.

\section{The Evergreen-Er, Ever-Ebony-Orwell}

All that already seems like ancient history in our nanosecond news-hole era, as 2020 and the election season proceed apace. Given the current state of affairs, in which incursions into and even abrogation of our personal freedoms are so frequent as to render them a casual, matter-of-fact norm of contemporary life-Future Shock indeed!-I believe that George Orwell would voice anew his anxieties of yesteryear. Ah, "if Orwell were alive today...!"

Whether applied to state torture or techno-trespass, his novel's cautionary warnings are unfortunately evergreen —or ever-ebony.

Johan Rodden, Senior Editor of Society, is the author, most recently of George Orwell: Life and Letters, Legend and Legacy (Princeton University Press). He would like to issue a special word of thanks to Jimmy Margulies, the award-winning, nationally syndicated political satirist who contributed the cartoon accompanying this article. 